\title{
Transparency in Local State-Owned Enterprises in Italy ${ }^{*}$
}

\author{
Marco Bertocchi**
}

\begin{abstract}
Transparency, integrated with corruption prevention measures, is one of the key answers provided by the Italian legislator to face the problem of the inefficiencies of Local SOEs. While, according to the international guidelines formulated by the OECD, SOEs should follow the same standards of transparency and disclosure adopted by listed companies, the approach followed in Italy is to assimilate SOEs to public administrations by providing them the same transparency regime as "compatible". An important exception concerns listed publicly owned companies, for which a "lighter" public transparency regime integrates the transparency and disclosure measures generally provided for listed companies.
\end{abstract}

Keyword: State-Owned Enterprises; Transparency; Disclosure; Corruption; Public Control; Public Interest Activities; Publicly-Owned Enterprises

\section{Transparency and Disclosure in Publicly-Owned Enterprises}

State-Owned Enterprises (SOEs) and Local State-Owned Enterprises (L-SOEs) ${ }^{\mathrm{i}}$ play an important role in global and local markets. How well these publicly-owned enterprises are governed has a significant impact on their performance and value, as well as on public finances, economic growth and competitiveness. Transparency and accountability are key to investment, growth and competitiveness. Publiclyowned enterprises which are transparent and accountable are more likely to conform to the rule of law, including respecting shareholder, stakeholder and citizens' rights. They enjoy higher levels of public trust and have better access to capital at lower cost. In most countries, improving transparency and disclosure in publicly-owned enterprises is seen like a key measure to prevent corruption ${ }^{\mathrm{ii}}$, to promote integrity and to assure a good corporate governance. This implies the need to face some distinct governance challenges.

On the one hand, publicly-owned enterprises may suffer from undue political interferences, leading to unclear lines of responsibility, a lack of accountability and efficiency losses in corporate operations. On the other hand, a lack of any control can weaken the incentives of management to perform in the best interest of the enterprise and the general public (who are its ultimate shareholders), and raise the

\footnotetext{
* Invited Article

** President, Independent Evaluation Unit Città Metropolitana di Milano (m.bertocchi@ farepa.it)
} 
likelihood of self-serving behavior by corporate insiders. Management of these enterprises may also be protected from two factors that are considered essential for management in private sector corporations, i.e. the possibility of takeover and the possibility of bankruptcy.

In such a complex context, the sensitivity towards the definition of corporate governance standards specific to public enterprises has increased.

In 2002, the OECD Working Group on Privatization and Corporate Governance of State Owned Assets started developing a set of non-binding guidelines for corporate governance of SOEs, in complement to the OECD Principles of Corporate Governance. After two years of consultation, the OECD Guidelines on Corporate Governance of State-Owned Enterprises (SOEs Guidelines) were adopted in April 2005.

In 2015, the SOEs Guidelines, which had served as a global benchmark for countries introducing governance reforms in the state-owned enterprises since their inception in 2005, were completely revised to take into account developments since their adoption and to reflect the experiences of 10 years implementation by a larger number of countries. The Guidelines are applicable to all SOEs pursuing economic activities, either exclusively or together with the pursuit of public policy objectives or the exercise of governmental authority or a governmental function ${ }^{\text {iii. }}$.

The SOEs Guidelines are founded on the principle that SOEs should respect high standards of transparency and be subject to the same high-quality accounting, disclosure, compliance and auditing standards as listed companies. Disclosure and transparency is one of the seven key principles defined by the Guidelines (Table 1).

Transparency is reflected in three statements that should be required for a good governance of these enterprises ${ }^{\text {iv. }}$ :

a) SOEs should report material financial and non-financial information on the enterprise in line with high quality internationally recognized standards of corporate disclosure, and including areas of significant concern for the state as an owner and the general public. This includes, in particular, SOE activities that are carried out in the public interest;

b) SOEs' annual financial statements should be subject to an independent external audit based on high-quality standards. Specific state control procedures do not substitute for an independent external audit;

c) the ownership entity should develop consistent reporting on SOEs and publish annually an aggregate report on SOEs. Good practice calls for the use of web-based communications to facilitate access by the general public.

Table 1: Seven Principles of Corporate Governance of SOEs

\begin{tabular}{|c|l|}
\hline I & Rationales for state ownership \\
\hline II & The state's role as an owner \\
\hline III & State-owned enterprises in the marketplace \\
\hline IV & Equitable treatment of shareholders and other investors \\
\hline V & Stakeholder relations and responsible business \\
\hline VI & Disclosure and transparency \\
\hline VII & The responsibilities of the boards of state-owned enterprises \\
\hline
\end{tabular}

Source: OECD (2015). 
These statements focus on the completeness and quality of information of the enterprise, on the need for independent auditing, and on a specific role of the ownership entity. The SOEs Guidelines further develop the first statement, by individuating the main categories of information that should be required for a transparent governance ${ }^{\mathrm{v}}$ :

1. a clear statement to the public of enterprise objectives and their fulfilment;

2. enterprise financial and operating results, including where relevant the costs and funding arrangements pertaining to public policy objectives;

3. the governance, ownership and voting structure of the enterprise, including the content of any corporate governance code or policy and implementation processes;

4. The remuneration of board members and key executives;

5. Board member qualifications, selection process, including board diversity policies, roles on other company boards and whether they are considered as independent by the SOE board;

6. Any material foreseeable risk factors and measures taken to manage such risks;

7. Any financial assistance, including guarantees, received from the state and commitments made on behalf of the SOE, including contractual commitments and liabilities arising from public-private partnerships;

8. Any material transactions with the state and other related entities;

9. Any relevant issues relating to employees and other stakeholders.

According to the SOEs Guidelines, the extension of transparency and disclosure should be related to enterprises size and to their commercial orientation. It also should not compromise the competitiveness of the enterprise in the marketplace ${ }^{\mathrm{vi}}$.

Although the guidelines are specifically devoted to state-owned enterprises, they may, with due adaptation, be extended to companies owned by local authorities. This is particularly true for enterprises that provide services of general economic interest.

Anyway, 2015 OECD SOE Guidelines can represent a strong benchmark for all countries engaged on transparency reforms addressed to publicly owned enterprises. In the past few decades, many countries have taken a number of steps over the years to improve the efficiency and performance of state-owned enterprises. There has been some progress in terms of developing improved information disclosure by SOEs with an accelerated corporatization process of SOEs and application of adequate accounting standards. However, countries differ in terms of their degree of efforts and progress to develop and implement their SOE corporate disclosure and transparency. "Many economically significant SOEs in the world still have not yet put in place comprehensive legal and regulatory framework for enhancing disclosure and transparency nor being systematically subject to high-quality international accounting and auditing standards. Also, many governments are not equipped with the system for detecting fiscal risk and contingent liabilities linked to SOEs"vii. 


\section{The Context of Local State-Owned Enterprises in Italy}

In Italy, the focus on the public participations system has been growing both at the central and the territorial level, as the conviction that the use of the corporate tool can constitute a way of circumventing public finance constraints. In this respect, the legislator's constant attention is drawn to those behaviors that, although legitimate, are aimed at avoiding compliance with the new public finance rules ${ }^{\text {viii }}$. The phenomenon has spread nationally, but local government represents the institutional level in which the corporate tool has been used most frequently. LSOEs in Italy have proliferated during the last two to three decades: the local public sector made an extensive use of the private law corporate structures in order to perform certain missions of its own, seeking for flexibility outside the bureaucratic structures and the related constraints on the use of public money (e.g. public procurement, recruiting, budget constraints), which were becoming more and more strong ${ }^{\text {ix }}$.

A large number of publicly and semi-publicly-owned enterprises, and other noncorporate entities (Table 2), have emerged, particularly at the regional and municipal level, active in several areas:

- accomplishment of tasks of public interest;

- management of state assets;

- provision of local public services;

- provision of services on the open market like the standard private players.

Corporate entities are the main tool used by local authorities to implement economic activities.

Table 2: Enterprises and other Entities owned by Local Authorities, distinct by Legal Form and Type of Participation

\begin{tabular}{|c|c|c|c|c|c|c|c|}
\hline \multirow{3}{*}{ Legal form } & \multicolumn{7}{|c|}{$\begin{array}{c}\text { Type of } \\
\text { participation }\end{array}$} \\
\hline & \multicolumn{3}{|c|}{ Totally public } & \multirow{2}{*}{$\begin{array}{c}\text { Mixed with } \\
\text { public } \\
\text { prevalence }\end{array}$} & \multirow{2}{*}{$\begin{array}{c}50 \% \text { public } \\
\text { and } 50 \% \\
\text { private }\end{array}$} & \multirow{2}{*}{$\begin{array}{l}\text { Mixed with } \\
\text { private } \\
\text { prevalence }\end{array}$} & \multirow[b]{2}{*}{ Total } \\
\hline & $\begin{array}{c}\text { Unique } \\
\text { shareholder or } \\
\text { partecipant }\end{array}$ & $\begin{array}{c}\text { More } \\
\text { shareholders or } \\
\text { participants }\end{array}$ & Total & & & & \\
\hline Jont stock company & 297 & 299 & 596 & 744 & 15 & 508 & 1.863 \\
\hline Limited liability company & 689 & 295 & 984 & 611 & 23 & 536 & 2.154 \\
\hline Consortium company & 12 & 93 & 105 & 326 & 5 & 270 & 706 \\
\hline Cooperative company & & 11 & 11 & 46 & & 135 & 192 \\
\hline Consortium & 9 & 231 & 240 & 519 & 13 & 97 & 869 \\
\hline Foundation & 113 & 74 & 187 & 170 & 21 & 194 & 572 \\
\hline Institution & 135 & 5 & 140 & 3 & & & 143 \\
\hline $\begin{array}{l}\text { Municipal enterprise } \\
\text { ("Azienda speciale") }\end{array}$ & 181 & 16 & 197 & 29 & & & 226 \\
\hline Other forms & 90 & 92 & 182 & 211 & 5 & 58 & 456 \\
\hline TOTAL & 1.526 & 1.116 & 2.642 & 2.659 & 82 & 1.798 & 7.181 \\
\hline
\end{tabular}

Source: Corte dei Conti (2016)

In 2014, around $27 \%$ of the L-SOEs reported a loss, which suggests an underlying widespread problem of bad management (Table 3$)^{\mathrm{xi}}$. The percentage of loss-making SOEs was even higher before the crisis $(38.9 \%$ in 2007) indicating that this is a 
structural feature, and not a cyclical one $\mathrm{e}^{\mathrm{xii}}$.

Table 3: Number and amount of losses of L-SOEs

\begin{tabular}{|c|c|c|c|c|c|c|c|}
\hline \multirow[b]{2}{*}{ Type of participation } & \multirow{2}{*}{$\begin{array}{l}\text { Total L- } \\
\text { SOEs }\end{array}$} & \multicolumn{2}{|c|}{2012} & \multicolumn{2}{|c|}{2013} & \multicolumn{2}{|c|}{2014} \\
\hline & & $\begin{array}{c}\text { No. Loss- } \\
\text { making } \\
\text { SOEs }\end{array}$ & $\begin{array}{l}\text { Amount of } \\
\text { losses }\end{array}$ & $\begin{array}{l}\text { No. Loss- } \\
\text { making } \\
\text { SOEs }\end{array}$ & $\begin{array}{l}\text { Amount of } \\
\text { losses }\end{array}$ & $\begin{array}{c}\text { No. Loss- } \\
\text { making } \\
\text { SOEs }\end{array}$ & $\begin{array}{l}\text { Amount of } \\
\text { losses }\end{array}$ \\
\hline $\begin{array}{l}\text { Totally public with unique } \\
\text { shareholder or participant }\end{array}$ & 705 & 190 & 128.009 .454 & 172 & 167.726 .118 & 168 & 100.585 .908 \\
\hline $\begin{array}{l}\text { Totally public with more } \\
\text { shareholder or participant }\end{array}$ & 561 & 146 & 83.053 .488 & 146 & 121.708 .622 & 141 & 96.999 .148 \\
\hline Mixed with public prevalence & 1.390 & 394 & 418.828 .552 & 369 & 448.529 .370 & 365 & 246.306 .104 \\
\hline $50 \%$ public and $50 \%$ private & 28 & 8 & 611.699 & 7 & 435.947 & 5 & 113.683 \\
\hline Mixed with public prevalence & 770 & 276 & 237.454 .276 & 264 & 181.861 .029 & 258 & 292.809 .252 \\
\hline TOTAL & 3.454 & 1.014 & 867.957 .469 & 958 & 920.261 .086 & 937 & 736.814 .095 \\
\hline
\end{tabular}

Source: Corte dei Conti (2016).

Since several years, there is the need to improve the overall performance of Local SOEs, at both national and European level ${ }^{\mathrm{xiii}}$.

Among the reasons that required new reform measures, there is the finding that losses of L-SOEs are charged on public entities' budget, with transfers aimed at covering the deficits of these bodies and consequently contributing to the increase in public deficit. The European Commission recently underlined the importance of the governmental initiatives taken to tackle the root causes of inefficiency in stateowned enterprises and local public services. "The new framework aims to regulate systematically state-owned enterprises in line with the principles of efficient management, protection of competition and the need to reduce public expenditure. New L-SOEs need to be justified against other alternatives and fall within the institutional goals of the public authority, subject to prior control by the Court of Auditors. The latter shall also be responsible to review annual rationalization reports. The role of participating public authorities is aligned to the position of regular shareholders. [...] Important measures are also proposed to revise the legal framework for local public services in order to strengthen competition and improve efficiency"xiv . The response of the Italian legislator, during the last years, passes through a set of measures aimed at improving the overall performance and transparency of Local SOEs:

- introduction and reinforcement of specific internal controls on SOEs by local authorities, together with new external audits carried out by the Court of auditor (arts. 147Quater and 148 of Leg. Decree no. 267/2000, introduced by the Leg. Decree no. 274/2012, art. 19 Leg. Decree no. 175/2016);

- obligation to prepare the consolidated financial statements for local and regional authorities (Leg. Decree no. 118/2011);

- measures aimed at the rationalization of the Local State-Owned Enterprises, reducing the public intervention in sectors non-directly related to public policy functions (Law no. 190/2014, arts. 20 and 24 Leg. Decree no. 175/2016, 
modified by Leg. Decree no. 100/2017);

- introduction and reinforcement of transparency and disclosure measures, in the context of the whole system of corruption prevention, according to similar principles to those established for public administrations (Law no. 190/2012, Leg. Decree no. 33/2013, National Anticorruption Plan 2013, ANAC xv Guidelines no. 8/2015, National Anticorruption Plan 2016, Leg. Decree no. 97/2016, ANAC Guidelines 26/4/17, in consultation).

- Focusing on transparency and disclosure measures (Figure 1), some specific features of the evolution of Italian legislation can be highlighted:

- $\quad$ some transparency rules had previously been defined in 2009 with Leg. Decree no. 150/2009 ("Decreto Brunetta"). These rules affected only public administrations and were not extended to SOEs. SOEs were included into the scope of application of the rules on transparency and anti-corruption only with Law no. 190/2012;

- since Law no. 190/2012, transparency measures have been integrated into the anti-corruption strategy, both at the national and the local level. A key role, in this direction, has been played by the National Anticorruption Plans (NPA) released in 2013 and in 2016;

- a specific discipline for SOEs and L-SOEs was only defined in 2015 by ANAC Guidelines $^{\mathrm{xvi}}$. This means that the first two years of application of transparency rules for public enterprises were characterized by strong uncertainty. There were many difficulties in transposing rules defined for public administrations in the operational reality of enterprises governed by private law;

- the transparency reform introduced by Leg. Decree no. 97/16 has made significant changes in many aspects of the regulatory framework. In particular, this decree redefined the ways in which public enterprises should implement transparency measures (see more in the next chapters). For this reason, ANAC has released a draft of the new SOE guidelines on 26/4/2017 for consultation. At the time of writing, the final version of these guidelines has not yet been published.

Figure 1: Transparency: the Evolution of Italian Legislation for SOES

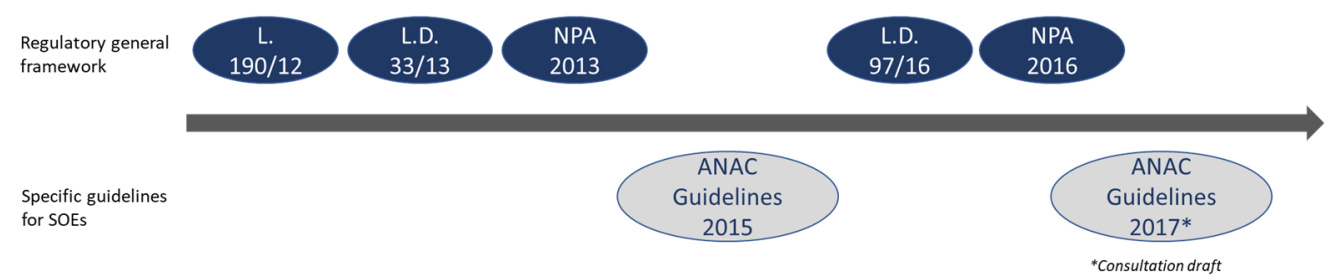

At present, the implementation of transparency and disclosure measures for LSOEs is based on the following principles:

- the definition of the scope of transparency for SOEs, using, as discriminatory criteria, the existence of public control and the management activities of public interest governed by national law or by the European Union;

- the definition of a specific organizational model for transparency management;

- a differentiated application framework in relation to the level of participation and / or control by public administrations. 


\section{The Scope of Application: Public Control and Activities of Public Interest As Discriminatory Criteria}

The transparency reform introduced by Leg. Decree no. 97/16 has modified the scope of application of transparency rules.

Article 2-bis of Leg. Decree no. 33/2013 replaces the old article 11 of the same decree. This new article:

- establishes an organic transparency discipline applicable to all public administrations;

- extends the same regime, 'as compatible', also to other public entities (not included in public administrations) and private (private companies and other private bodies controlled by public administrations);

- $\quad$ sets a different, less stringent, discipline for private law entities (companies and other bodies) only participated by public administrations, limited to public interest activities that they carry out.

Article 2-bis para. 2 makes an important exception to listed companies, excluding them from the application of the transparency measures provided for companies under public control. The existence of the requirement of public control and the pursuit of public interest activities are therefore the two main criteria used by the legislator to define the rules for the application of transparency measures by the SOEs. The new regulatory framework confirms the distinction made with ANAC Resolution no. 8/2015 between private law bodies controlled by public administrations, which are subject to transparency to both their organization and to the whole of their activities, and private law entities with public non-control participation, subject to transparency only in relation to public interest activities carried out (Figure 2).

Figure 2: Transparency: the Scope of Application for Local SOEs

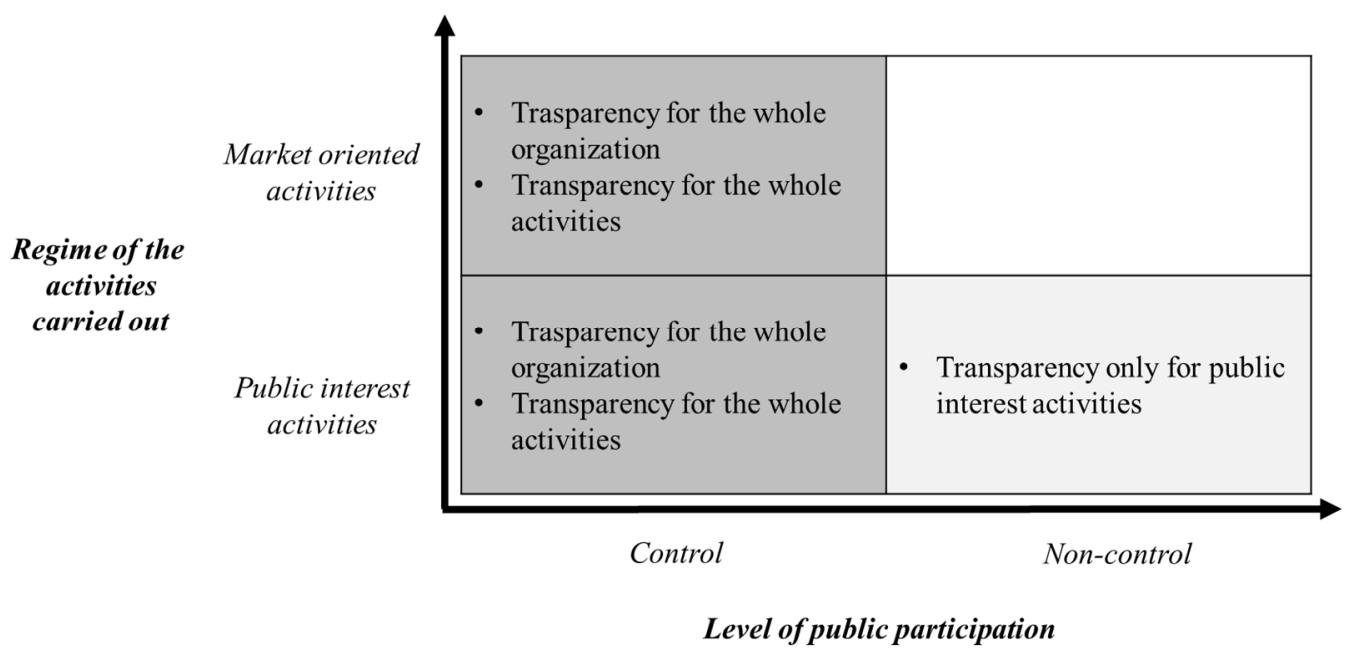

\subsection{The Concept of Public Control}


The new Art. 2-bis para. 2 lett. b) of Leg. Decree no. 33/2013 has expanded the definition of public control for companies previously used in the law of transparency, referring directly to the one provided by Leg. Decree no. 175/2016 ${ }^{\mathrm{xvii}}$.

Therefore, the definition of control includes:

- the cases already considered by the ANAC Resolution no. 8/2015, i.e. companies in which another company has a majority of the votes cast in the ordinary shareholders' meeting (Civil Code, Art. 2359, para. 1, point 1), and companies in which another company has voting rights sufficient to exercise dominant influence in the ordinary shareholders' meeting (Art- 2359, para. 1, point 2);

- the case in which a company is under the dominant influence of another company by virtue of particular contractual constraints with it (Art. 2359 para. 1 , point 3$)^{\mathrm{xviii}}$.

The definition of public control includes also the situation in which the control of a company is exercised jointly by a plurality of administrations, that is, in the case of fractional participation between several administrations which can determine a situation in which the company is still under public control ${ }^{\mathrm{xix}}$.

Conversely, the definition of "public participation company" refers to companies in which the public administration or a public controlled company holds a shareholding without control.

\subsection{The Concept of Public Interest Activities}

Article 2-bis para. 3 of Leg. Decree no. 33/2013 qualifies public interest activities such as 'Public interest activities governed by national or European Union law'.

This concept includes the exercise of administrative functions, the production of goods and services for public administrations and the management of public services. It follows that activities are certainly considered of public interest if they are so qualified by a statutory or constitutional law and by the statutes of the companies or by the service contract.

For a better clarification of the definition of public interest activities, the ANAC refers directly to art. 4 of Leg. Decree no. 175/2016, which lists the activities that allow public administrations to keep or buy shareholdings ${ }^{\mathrm{xx}}$. In addition to the activities that the law directly qualifies as of public interest, these are also those for which the rules of national law or the European Union provide for the attribution to the public administration of powers of regulation, supervision or control. The attribution of these powers suggests that the activity carried out should be of public interest. As a general guideline, ANAC ${ }^{\mathrm{xxi}}$ states that it is the burden of the individual companies, in agreement with the controlling or participating administrations, to clearly indicate which activities fall within those of "public interest governed by national or European Union law" and those which, instead, are not.

\section{The Organizational Model for Transparency Management}

The Leg. Decree no. 33/2013 (as modified by Leg. Decree 97/16) sets an 
organizational model for transparency management in SOEs which is based on these key aspects:

- the identification, within the organization, of a Responsible for Corruption Prevention and Transparency (RCPT);

- the obligation to publish data, documents and information regarding the organization and its activities;

- the creation of a specific section of the internet site, called 'Società trasparente', dedicated to the publication of such information;

- the civic access, by citizens, to data, documents and information held by the organization;

- the integration of transparency into corruption prevention measures.

This organizational model is based on the same principles defined for public administrations, but with some adaptations to the context of private law entities. It also has a different level of implementation depending on the level of public participation in the company ${ }^{\mathrm{xxii}}$.

\subsection{The Responsible for Corruption Prevention and Transparency}

With the reform carried out by the Leg. Decree no. 97/16 roles responsible for the prevention of corruption and responsible for transparency have been unified into one.

As well as public administrations, SOEs must also appoint a RCPT. In order to make the appointment mandatory, companies adopt, preferably by means of statutory amendments, but possibly also in other forms, the appropriate adjustments, which in any case must contain a clear indication of the subject that will perform the functions of RCPT. The RCPT is appointed by the company's board of directors, or other bodies with equivalent functions. The nomination data must be transmitted to the ANAC. The ANAC states that RPCT functions should be entrusted to one of the company's executives ${ }^{x x i i i}$. The company's governing bodies therefore appoint as an RPCT a running officer at the company, assigning him, with the same act of assignment, the functions and powers appropriate for carrying out the assignment with full autonomy and effectiveness. When making this choice, the company will have to look at possible conflicts of interest and avoid, as far as possible, the designation of managers responsible for those areas within the company, among those with areas at greater risk of corruption. Regarding transparency, the RCPT:

- has a permanent control over the company's compliance with the publication requirements of the current legislation, ensuring the completeness, clarity and updating of the published information;

- reports to The Board of Directors, the Supervisory Body provided by Leg. Decree no. 231/2001 ${ }^{\text {xiv }}$ and to the ANAC, cases of non-fulfillment or delayed fulfillment of the obligation to publish;

- controls the regular implementation of civic access.

\subsection{The Publication of Mandatory Information}

L-SOEs must publish data, documents and information about their organization and activities in accordance with the provisions of Leg. Decree no. 33/2013. The 
ANAC guidelines provide, in a specific attachment, the specifications and adaptations that companies must carry out in relation to the obligations initially envisaged for public administrations ${ }^{\mathrm{xxv}}$.

\subsection{Website - Section 'Società trasparente'}

For L-SOEs it is not enough to ensure the publication of mandatory information. They are also obliged to set up on their own website a special section, called "Società trasparente", in which to publish the data and information pursuant to Legislative Decree no. 33/2013. In order to limit the burden of transparency, if the companies do not have a website, the parent administrations will have to make available a section of their site where the subsidiaries can set up the "Società trasparente" section and publish the data, without prejudice to their respective responsibilities.

\subsection{Civic access}

The reform made by Legislative Decree no. 97/2016 has expanded the definition of civic access, dividing it into two types ${ }^{\mathrm{xxvi}}$ :

- 'simple' civic access, already regulated by the previous legislation, concerning the right of anyone to apply for a public administration to publish compulsory information by law if he has not yet done so;

- 'generalized' civic access, consisting in the right of anyone to request access to data, documents and information held by public administrations, further than those for which mandatory publication is required, while respecting the limits of public and private interests protected by the law.

L-SOEs are also required to implement both 'simple' civic access, and 'generalized' civic access.

'Generalized' civic access is provided for data, documents and information that are not already published in compliance with the publication requirements already indicated, and it is subject to the limits set forth in Article 5-bis of Legislative Decree no. 33/2013.

\subsection{Integration of transparency in corruption prevention measures}

Integration of transparency into anti-corruption measures is one of the main key aspects of the reform made by Legislative Decree no. 97/2016.

For this reason, the obligation to draw up a specific Triennial Plan for Transparency has been abolished. Now, L-SOEs are obliged to include transparency measures in a special section of the document containing the 'Model 231' supplementary corruption prevention measures, or the only document containing together the integrative measures and measures of the "Model 231"xxvii. This section identifies organizational measures to ensure the regularity and timeliness of the flow of information to be published, including a specific system of responsibilities and indicating the names of those responsible for the transmission and publication of data, information and documents for which are subject to the 
obligation of publication. The objectives of transparency must therefore be articulated and detailed not only in relation to the RCPT but also to the other parties involved in the implementation of the transparency measures provided by the rules or introduced by the company itself.

\section{A Differentiated Level of Implementation}

The Legislative Decree no. 33/2013 and the ANAC Guidelines define a differentiated level of implementation of the organizational model of transparency management described in the previous chapter.

First of all, it should be noted that Article 2-bis of Legislative Decree no. 33/2013 extends the transparency regime for public administrations to other public and private entities 'as compatible'.

ANAC states that the compatibility clause should be assessed in relation to the typology of entities and companies, taking due account of the distinctive features that characterize their structure: compatibility, therefore, should not be examined case by case but should be evaluated in general $^{\text {xxviii }}$.

Regarding to L-SOEs, compatibility should be assessed in relation to the type of activities carried out, distinguishing between:

- activities that certainly are of public interest;

- activities exercised in competition with other economic operators.

Finally, it is necessary to have regard to the regulatory regime already applicable to different types of entities based on other regulatory sources, in order to avoid duplication of obligations.

The way companies must implement this model depends on the level of public participation in their share capital. A special discipline is provided for listed companies (Table 4).

Table 4: Implementation of Transparency Measures in Different Types of SOEs

\begin{tabular}{|l|c|c|c|}
\cline { 2 - 4 } \multicolumn{1}{c|}{} & $\begin{array}{c}\text { Companies under } \\
\text { public control }\end{array}$ & $\begin{array}{c}\text { Companies under } \\
\text { public participation }\end{array}$ & Listed companies \\
\hline $\begin{array}{l}\text { Responsible for Corruption } \\
\text { Prevention and Transparency }\end{array}$ & Yes & Not mandatory & Not mandatory \\
\hline $\begin{array}{l}\text { Publication of mandatory } \\
\text { information }\end{array}$ & $\begin{array}{c}\text { Whole organization } \\
\text { Whole activities }\end{array}$ & $\begin{array}{c}\text { Only public interest } \\
\text { activities }\end{array}$ & $\begin{array}{c}\text { Only public interest } \\
\text { activities }\end{array}$ \\
\hline $\begin{array}{l}\text { Website - Section "Società } \\
\text { trasparente" }\end{array}$ & Yes & Not mandatory & Not mandatory \\
\hline $\begin{array}{l}\text { Civic access } \\
\text { Integration of transparency in } \\
\text { corruption prevention measures }\end{array}$ & Yes & $\begin{array}{c}\text { Only information } \\
\text { related to public interest } \\
\text { activities }\end{array}$ & $\begin{array}{c}\text { Only information } \\
\text { related to public } \\
\text { interest activities }\end{array}$ \\
\hline
\end{tabular}

Companies which are under public control must implement all transparency measures at the same way of public administrations, taking into account the compatibility clause previously described.

This means they must meet all the requirements of the organizational model of transparency management, with all the adaptations provided by ANAC Guidelines.

In particular, Annex 1 of ANAC Guidelines shows how companies must meet the 
various disclosure requirements, by adapting the type of information required in their context.

Companies under public participation, in the absence of public control, are characterized by a lighter implementation of the organizational model of transparency.

They are not required to nominate the RCPT, but may still locate that figure within their autonomy, preferably in compliance with the ANAC Guidelines.

However, they should provide, in their organization, a function of monitoring and certifying compliance with the publication requirements. As with companies under public control, this function must be preferably entrusted to the Supervisory Body under Leg. Decree no. 231/2001, without prejudice to the internal organizational choices considered most appropriate, given the need to limit organizational costs and to simplify and to enhance existing control systems.

The implementation of publication requirements is limited to 'public interest activities governed by national or European Union law``

Implementation of civic access also meets this limit.

These companies are not obliged to implement the discipline on corruption prevention.

However, the ANAC suggests that the participating public administrations promote the adoption of the 'Model 231'. Also in this case, according to the ANAC guidelines, this model should be integrated, preferably in a special section, with organizational and management measures proper to prevent corruption in their activities ${ }^{\ddagger}$.

As far as transparency is concerned, even if they are not obliged to draw up a specific document integrating corruption prevention measures into the 'Model 231', these companies should fully regulate how to ensure the correctness and timeliness of information flows and civic access to data by publishing on their institutional site the names of the persons responsible for the transmission and publication of the data and documents, as these are activities subject to the law.

With reference to listed companies, article 2-bis of Leg. Decree no. 33/2013 provides for a specific regime based on two principles:

a) the exclusion of listed companies from the strict rules applied to companies under public control;

b) the use of the definition of 'listed company' adopted by Leg. Decree no. $175 / 2016$.

According to the interpretation of article 2-bis para. 2 provided by the ANAC guidelines, listed companies (controlled or participated by public administrations) remain, in any case, subject to the regime of public-participation companies, referring solely to activities of public interest, not to all activities or to whole organization.

This means that they must implement the transparency organizational model at the same way of non-listed companies only participated by public administrations.

The choice of providing a 'lighter' public transparency regime for listed stateowned companies (centrally and locally owned):

a) is consistent with the choice made by the legislator on the rationalization of

${ }^{+}$See chapter 3.2 .

${ }^{\ddagger}$ ANAC 2017, p. 24. 
SOEs. In the broad definition of art. 2, para. 1, lett. p) of Leg. Decree no. $175 / 2016$, listed companies are excluded from the application of the rules on the reorganization of the presence of public administrations in companies.

b) can be justified by the fact that these companies are considered to have been fully and effectively privatized, and therefore excluded from the perimeter of the public sector;

c) must be considered in the light of the fact that, as listed, such companies are subject to a specially qualified transparency regime.

The approach taken by the Italian legislator on the transparency of L-SOEs can therefore be summarized in these key points:

a) a transparency regime similar to that of public administrations for unlisted companies that are under public control. These companies are completely assimilated to public administrations;

b) a 'public' transparency regime limited to public interest activities for listed companies held by public administrations. For these companies, this regime is supplemented by the transparency and disclosure measures generally provided for listed companies;

c) a 'public' transparency regime limited to public interest activities for unlisted companies with public participation but not control. For these ones, the choice to maintain public participation should be assessed in accordance with the rules of Leg. Decree no. 175/2016 on the rationalization of publicly owned companies.

\section{Bibliography}

ANAC (2015). Guidelines for the implementation of legislation on the prevention of corruption and transparency by companies and entities under private law controlled and participated by public administrations and public economic entities, Resolution no. 8/2015, (www.anticorruzione.it), June 2015.

ANAC (2017). Update of the Guidelines for the implementation of legislation on the prevention of corruption and transparency by companies and private-law entities controlled and participated by public administrations and public economic bodies, Resolution no. 1134/2017, (www.anticorruzione.it), 26/4/2017.

Appolloni A., Risso M., Zhang T. (2013). Collaborative Approach for Sustainable Auditing of Global Supply Chains, Symphonya. Emerging Issues in Management (symphonya.unimib.it), 2, 19 $-31$

http://dx.doi.org/10.4468/2013.2.02appolloni.risso.zhang

Arrigo E. (2006). Code of Conduct and Corporate Governance, Symphonya. Emerging Issues in Management (symphonya.unimib.it), 1, 93-109.

http://dx.doi.org/10.4468/2006.1.07arrigo

Brondoni S.M. (2015). Global Networks, Outside-In Capabilities and Smart Innovation, Symphonya. Emerging Issues in Management (symphonya.unimib.it), n. 1, pp. 6 - 21 . http://dx.doi.org/10.4468/2015.1.02brondoni

Brondoni S.M. (2014). Global Capitalism and Sustainable Growth. From Global Products to Network Globalisation, Symphonya. Emerging Issues in Management (symphonya.unimib.it), n. 1 , pp. $10-31$.

http://dx.doi.org/10.4468/2014.1.02brondoni 
Brondoni S.M. (2006). Managerial Corporate Governance Communication, Symphonya. Emerging Issues in Management (symphonya.unimib.it), 1, 8-23.

http://dx.doi.org/10.4468/2006.1.02brondoni

Corte dei conti (2016). Gli organismi partecipati dagli Enti territoriali - Osservatorio sugli organismi partecipati/controllati dai Comuni, Province e Regioni e relative analisi, Corte dei conti, Sez. Autonomie, Del. no. 27/2016.

European Commission (2016a). Local State-Owned Enterprises in Italy: Inefficiencies and Ways Forward, Economic Brief 010, April 2016.

European Commission (2016b). Country Report Italy 2016, SWD(2016) 81 final, Brussels, 26/2/2016.

Gnecchi F. (2006). Corporate Governance Communication, Symphonya. Emerging Issues in Management (symphonya.unimib.it), 1, 47-61.

http://dx.doi.org/10.4468/2006.1.04gnecchi

OECD (2015). OECD Guidelines on Corporate Governance of State-Owned Enterprises, p. 14, (www.oecd.org), July 2015.

OECD (2016a). Summary Record of the OECD Integrity Forum Session, In the Public Interest: Preventing Corruption in State-Owned Enterprise (www.oecd.org), April 2016.

OECD (2016b). Transparency and disclosure measures for state-owned enterprises (SOEs): Stocktaking of national practices, (www.oecd.org), June 2016.

Salvioni D. M. (2010), Intangible Assets and Internal Controls in Global Companies, Symphonya. Emerging Issues in Management, n. 1, p. 39-51.

http://dx.doi.org/10.4468/2010.2.04salvioni

Salvioni D. M., Bosetti L. (2014), Sustainable Development and Corporate Communication in Global Markets, Symphonya. Emerging Issues in Management (symphonya.unimib.it), 1, 1-19. http://dx.doi.org/10.4468/2014.1.03salvioni.bosetti

Salvioni D.M., Astori R. (2013), Sustainable Development and Global Responsibility in Corporate Governance, Symphonya. Emerging Issues in Management (symphonya.unimib.it), 1, 28-52. http://dx.doi.org/10.4468/2013.1.03salvioni.astori

Salvioni D. M., Bosetti L. (2006), Corporate Governance Report and Stakeholder View, Symphonya. Emerging Issues in Management (symphonya.unimib.it), 1, 24-46. http://dx.doi.org/10.4468/2006.1.03salvioni.bosetti

Sturesson, J., McIntyre, S., \& Jones, N.C., (2015). State-Owned Enterprises Catalysts for public value creation?, PwC, www.psrc.pwc.com, April 2015.

Tu W. (2011). Assessing Urban Environmental Management Practice with a Scalar Approach. The Shanghai Case, Symphonya. Emerging Issues in Management (symphonya.unimib.it), 2, 60-74 http://dx.doi.org/10.4468/2011.2.06tu

\section{Notes}

${ }^{\text {i }}$ SOEs can be defined as enterprises where the state has significant control through full, majority, or significant minority ownership. In this definition we include SOEs which are owned by the central or federal government, as well as SOEs owed by regional and local governments.

By defining L-SOEs, we focus on enterprises wholly or partially owned by local governments, at the regional, provincial and municipal level.

ii "To prevent corruption in SOEs, corporate structures must be clearly delineated from general government. As owners, the governments should have control—but the right form of control, for example via government directors on the board. Their roles and responsibilities, however, should be distinguished from the professional management of the SOE. SOEs should also apply international rules on transparency and disclosure and should have strong internal audit functions that report to the audit committee of the board" OECD (2016a), Summary Record of the OECD Integrity Forum Session, "In the Public Interest: Preventing Corruption in State-Owned Enterprises" (www.oecd.org), April 2016. 
iii OECD SOEs Guidelines define a SOE as any corporate entity recognised by national law as an enterprise in which the state exercises ownership. "This includes joint stock companies, limited liability companies and partnerships limited by shares. Moreover, statutory corporations, with their legal personality established through specific legislation, should be considered as SOEs if their purpose and activities, or parts of their activities, are of a largely economic nature" OECD (2015), "OECD Guidelines on Corporate Governance of State-Owned Enterprises", p. 14, (www.oecd.org), July 2015 .

The Guidelines are generally not intended to apply to entities or activities whose primary purpose is to carry out a public policy function, even if the entities concerned have the legal form of an enterprise. As a guiding principle, those entities responsible for the ownership functions of enterprises held at subnational levels of government should seek to implement as many of the recommendations in the Guidelines as applicable. OECD (2015), p. 16.

iv OECD (2015), p. 24.

${ }^{\mathrm{V}}$ OECD (2015), p. 24.

${ }^{v i}$ For SOEs of a small size not engaged in public policy activities, disclosure requirements should not be so high as to effectively confer a competitive disadvantage. Conversely, where SOEs are large or where state ownership is motivated primarily by public policy objectives, the enterprises concerned should implement particularly high standards of transparency and disclosure.

On one hand, SOEs should face at least the same disclosure requirements as listed companies. But on the other hand, disclosure requirements should not compromise essential corporate confidentiality and should not put SOEs at a disadvantage in relation to private competitors. vii OECD (2016b), Transparency and disclosure measures for state-owned enterprises (SOEs): Stocktaking of national practices, p. 9, (www.oecd.org), June 2016. The report makes a comparison between national practices in promoting and implementing transparency and disclosure measures addressed to SOEs, focusing on 12 countries: Argentina, Brazil, India, South Korea, Lithuania, Malaysia, Mexico, Paraguay, Peru, Philippines, Sweden, Viet Nam.

viii Corte dei conti (2016), "Gli organismi partecipati dagli Enti territoriali - Osservatorio sugli organismi partecipati/controllati dai Comuni, Province e Regioni e relative analisi”, p. 3, Corte dei conti, Sez. Autonomie, Del. no. 27/2016.

${ }^{\text {ix E}}$ European Commission (2016a), "Local State-Owned Enterprises in Italy: Inefficiencies and Ways Forward", p. 3, Economic Brief 010, April 2016

${ }^{\mathrm{x}}$ European Commission (2016a), p. 3.

${ }^{x i}$ Corte dei Conti (2016), p. 110.

${ }^{x i i}$ European Commission (2016a), p. 5.

xiii Roots of SOEs' inefficiencies in different countries have been in the spotlight of several studies and discussed on multiple occasions. The debate on the local SOEs in Italy points to a multiform state participation in the economy for different reasons and with no clear orientation. Lack of competition, political interventions, and a complicated regulatory framework, are some of the main reasons of the weakness of SOEs.

"In Italy, a SOE, whether centrally or locally owned, is in principle an entity organized and operating under private law (incl. civil law, company law), as is the case with the ordinary commercial companies that are privately held. A large number of SOEs therefore have the legal form of joint stock companies or limited liability companies. Nevertheless, the Italian legislators have been adding several derogations and special provisions to the said framework, in the view of the public interest usually attached to the operation of SOEs or other objectives pursued. Only listed SOEs demonstrate no significant deviations from privately held companies". European Commission (2016a), p. 7.

xiv European Commission (2016b), "Country Report Italy 2016”, p. 66, SWD(2016) 81 final, Brussels, 26.2.2016.

${ }^{x v}$ ANAC (Autorità Nazionale Anticorruzione) is the Italian Anticorruption Authority.

xvi The ANAC 2015 Guidelines were released with Resolution no. 8/2015 and were addressed not only to SOEs, but also to other private and public entities controlled or participated by public administrations.

xvii As seen in chapter 2, the Legislative Decree no. 175/2016 defines a set of measures aimed to the rationalisation and the reduction of companies in which public administrations hold participations. 
xviii This is a hypothesis of control that does not originate in the ordinary assembly, but in an objective and external conditioning of the corporate activity, which is independent of the presence of a participation in the capital and in the group of shareholders who appoint the directors, but it directly affects the economic activity. A contractual control position is only presumed where the negotiating constraints are such that they generate a dominant influence equivalent to that conferred by the possession of the majority of the votes exercisable in the ordinary shareholders' meeting. Therefore, such control does not exist where the presumed subsidiary company may disengage from the contractual constraints that bind it to the parent company and establish identical contractual relations with other companies.

xix (ANAC 2017) ANAC Guidelines 2017, p. 7.

${ }^{x x}$ Article 4 of Legislative Decree no. 175/2016 identifies the activities for which public administrations can, directly or indirectly, constitute companies and buy or keep shareholdings in companies:

a) production of a service of general interest, including the realization and management of the networks and of the functional installations for the same services;

b) design and implementation of a public work based on a program agreement between public administrations;

c) realization and management of a public work, or organization and management of a service of general interest through a public private partnership;

d) self-production of instrumental goods or services to the body or public bodies participating in the company, where permitted by European and national law;

e) procurement services provided in support of non-profit organizations and contracting authorities referred to in Legislative Decree no. 50 of 2016.

${ }^{x x i}$ ANAC (2017), p. 11.

xxii See chapter 5 .

xxiii ANAC (2017), p. 17.

xxiv The ANAC 2017 guidelines give the supervisory body under Legislative Decree no. 231/2001 the same functions as the law attributes to Independent Performance Evaluation Bodies established in public administrations. ANAC (2017), p. 18.

${ }^{x x v}$ ANAC 2017 guidelines have amended the disclosure requirements for L-SOEs, previously released with Resolution no. 8/2015, in accordance with the novelties introduced by Legislative Decree no. 97/2016. Annex 1 provides, in any case, a detailed framework of information that companies must publish.

xxvi Article 5 of Leg. Decree no. 33/2013 as amended by Leg. Decree no. 97/2016. The definitions of "simple civic access" and "generalized civic access" have been given by ANAC with Resolution no. 1309/2016, "Linee guida recanti indicazioni operative ai fini della definizione delle esclusioni e dei limiti all'accesso civico di cui all'art. 5 co. 2 del D.lgs. 33/2013”.

xxvii In order to simplify the approach to corruption prevention in companies, NPA 2016 doesn't oblige them to adopt a specific Prevention Corruption Plan (like the one provided for public administrations). It requires, instead, that companies define corruption prevention measures by integrating them into the organizational model adopted in response of Leg. Decree 231/2001. This decree regulates the administrative liability of companies and other bodies in the commission of various types of crimes.

xxviii ANAC (2017), p. 12. 